Vol. 12 (1): 77-86 (2022)

\title{
PERCEIVED-HOTELSCAPES AND ITS IMPACT ON CUSTOMER PATRONAGE: AN EMPIRICAL PERSPECTIVES
}

\author{
Heyam Abdulrahman Al Mousa ${ }^{1}$, Haseebullah Abdul Naeem ${ }^{1 *}$, \\ Zainab Mohammed Alwan Al- Juboori ${ }^{2}$ \\ ${ }^{1 *}$ King Saud University, College of Business Administration, Department of Marketing, Riyadh, Saudi Arabia; \\ ${ }^{2}$ Universiti Teknologi Malaysia, Azman Hashim International Business School, Kuala Lumpur, Malaysia; \\ *Corresponding Author Haseebullah Abdul Naeem, e-mail: Haseebullah5@gmail.com; \\ healmousa.@ksu.edu.sa; maazainab2.@graduate.utm.my;
}

Received October 2021; Accepted November 2021; Published January 2022;

DOI: https://doi.org/10.31407/ijees12.109

\begin{abstract}
This study reviews the impact of hotelescapes elements on customer cognitive responses and customer patronage in Saudi Arabia. This study explored the moderation role of customer motivation. The present study was developed after a systematic review of past literature. The present study found the critical influence of the study's variables on customer patronage. Furthermore, the study provided some understanding of how hotelescapes affect customer patronage in Saudi Arabia. Three hundred and nine (319) usable responses were obtained. Data were analyzed using Statistical Package for Social Science (SPSS) and Partial Least Square-Structural Equation Modeling (PLS-SEM). The study's findings show a positive and significant relationship between hotelescapes and customer patronage and cognitive responses. At the same time, there was no evidence showed to support the moderation effect of customer motivation. Stimulus Organism and Response (S-O-R) theory was used to underlie the conceptual framework. In addition, some implications of this conceptual model for theory and practice are discussed.
\end{abstract}

Keywords: Hotelescapes, Customer Patronage, Customer Cognitive Responses, Customer Motivation 